Physics, chemistry, mathematics, astronomy, geology, geophysics, psychology and biology are all represented on the Board. Many biologists are planning for research undertakings in outer space and to provide a forum for their discussions and planning an Armed Forces-National Research Council Committee on Bio-astronautics has been established.

The Committee on Fire Research has recently broadened the scope of its interests to include consideration of the causes and control of all unwanted fires, such as forest fires, and publication of Fire Research Abstracts and Reviews as a periodical was commenced. A Research Correlation Conference on "Noise Control in Buildings" was sponsored by the Building Research Institute and a committee set up for the study of agricultural pests and their control. Two temporary committees were appointed to supplement the work of the Materials Advisory Board, one to consider and define the more promising areas of research in solid-state physics and metallurgy, and the other to deal with tho organization and support of materials research in the universities, industry and government.

The Division of Medical Sciences commenced a survey of needs in tropical medicine, and its Committee on the Cardiovascular System is seeking to stimulate interest in research into the central nervous control of circulation, but the Committee on Infectious Diseases and Chemotherapy is being dissolved to make way for a more fundamentally oriented group. The activities of the Division of Chemistry and Chemical Technology markedly increased, particularly in the international field; the Division of Engineering and Industrial Research was also much occupied, and its Committee on Ship Steel and Ship Structural Design continued to assist the research programme of the inter-agency Ship Structure Committee by formulating research programmes in these fields. These include a study of the influence of metallurgical structure on the brittle behaviour of ship steel, a comparison of the influence of manganese, carbon and other elements on notchimpact properties, and efforts to increase knowledge of the response by ships to ocean waves and of brittle fracture mechanics.

The Office of International Relations has worked vigorously to foster exchanges of scientists between the United States and the U.S.S.R. and to facilitate travel there of United States scientists. A programme of reciprocal exchanges was negotiated between the Academy and the Academy of Sciences of the U.S.S.R. and arrangements were made for the participetion of United States scientists in more than thirty international scientific meetings.

\title{
RECRUITS TO TEACHING IN GREAT BRITAIN
}

\begin{abstract}
A $\mathrm{N}$ inquiry by $\mathrm{F} . \mathrm{W}$. Land, of the University of A Liverpool, was undertaken primarily in order to investigate the factors which were restricting the recruitment of a sufficient number of students in training colleges who were able and willing to teach mathematics and science*. This problem must be looked at as a facet of the larger problem of producing the whole body of teachers who should have, between them, a proper balance of subject interests. Although smaller in number, the trained graduates from universities take a role in this balance which, in many respects, is crucial, since they provide the greater part of the staffs of grammar schools from which are recruited the majority of the training college students.

The problem of university teacher-training departments is that mathematics and science graduates are not coming forward for training as teachers, whereas the training college problem is that those who are electing to train as teachers are reluctant to study mathematics and science. The Association of Teachers in Colleges and Departments of Education report of 1956 made it clear that this can only be brought about by a manifold increase in the number of mathematics and science graduates coming forward to train for service in both grammar schools and training colleges. This, in turn, depends on the ability of the universities to recruit more mathematics and science students and upon the willingness of industry to curb its seemingly insatiable domand for mathematics and science graduates.

Any future increase in the number of science undergraduates will depend on the ability of schools
\end{abstract}

* Recruits to Teaching : a Study of the Attainments, Qualifications and Attitudes of Students entering Training Colleges. By F. W. Land. Pp. 83. (Liverpool: The University Press, 1960.) 78. 6d. net. to supply further recruits able to undertake university courses, and this, in turn, is dependent upon a supply of science teachers. For the time being, until the critical supply of teachers has been rectified, industrialists should be asked how many of the posts now being filled by graduates could be filled with less highly qualified persons without substantially reducing industrial efficiency.

Mathematics and science pose problems for the training colleges which are of a different nature. Throughout the infant and junior schools almost all teachers are called upon to teach arithmetic. In secondary schools there is no possibility for years of having enough properly qualified teachers to provide specialist mathematics teachers for all children, and it is a debatable point whether studies such as English and mathematics, which are basic to all other studies, should be taught by specialists throughout the secondary schools. Most secondary teachers must expect to teach some arithmetic at least, even if the more specialized parts of the mathematics syllabus are in the hands of specialists. For this reason the arithmetical competence of all training college students is a matter of direct and intimate importance to their teaching.

Science teaching will be much more in the hands of the specialists. In secondary schools, specialists with responsibilities for laboratories must teach the greater part of science. In many junior schools in Britain almost no science is taught at all. Although it is highly desirable that more science be introduced into junior schools, it will not be highly specialized science calling for special qualifications, and any well-educated teacher ought to be able to cope with junior school science as he is expected to cope with junior school 
geography, history or handwork. The demands of schools are for an adequate proportion of students to be well qualified to serve as science specialists, and, in addition, it is desirable that all teachers should be informed about the basic nature of the scientific developments which are such a common feature of the environment in this second half of the twentieth century.

For all students, standards to be desired are: sufficient mastery in both English and mathematics to qualify them as competent to teach the subjects, a generally balanced education which includes a fair knowledge of and interest in all the main subjects of the curriculum, including chemistry and physics as well as history and geography and art and music, together with a more specialized interest in a particular subject which has been studied to the standards for examination at Advanced Level of the General Certificate of Education, and which will be their own individual contribution to the vitality of the teaching in their school. The interests of the schools require that the more specialized main studies should be so distributed among the teachers that the staffs of schools are not unduly biased in their interests and include representatives of all the main intellectual disciplines.

These desirable standards are fulfilled in respect of English. The fact that the outlook for English is so healthy with ontrants to training colleges is a reflexion of the fact that five times as many women honours graduates in English are being fed into schools by university departments as correspondingly qualified mathematicians.

In arithmetic and mathematics the position is most unsatisfactory. In mathematics only just over half the students enter training colleges with passes at Ordinary Level of the General Certificate of Education, women students rate it tenth on their lists of interests and $\mathbf{4 4}$ per cent say either that they dislike it or they derive no enjoyment from it. The Vernon Test discloses such gross shortcomings in simple arithmetic that many students will have to spend time on basic arithmetic in the course of their training. In Land's investigation only 193 women students out of 1,880 have elected to study mathematics as a main subject.

For the 90 per cent of students who are not taking main mathematics, provision must be made to give them ample opportunity to prepare themselves for whatever arithmetic and mathematics teaching comes their way. Approximately half of these soem to have sufficient competence to begin on a course which should have a two-fold aim. A necessary part of this course should be to interest them in using the mathematical skills they have, so that they begin to value their irreplaceable contribution to the understanding and appreciation of the world around them. This calls for the exercise of considerable imagination and versatility, and, at present, many training colleges do not find sufficient time on their time-tables to enable this task to be attempted with any hope of success. The other part of their course will be more closoly pedagogical and devoted to 'methods of teaching'.

For the other half of the students, these two courses need to be preceded and accompanied by a further course in basic arithmetic and mathematics. Such a course should begin with the assumption that there is no confident facility with number work. It must also take into account that achievement and understanding have been limited to arithmetic and that there is no background of appreciation of mathematical ideas to build on. It must start with the acceptance of shortcomings in the powers of visualization of mathematical concepts, and, so far as possible, begin with simple arithmetical processes and build up some picture of mathematical development without much recourse to abstract ideas, formulæ or formal geometry.

The staffing needs of mathematics ought to be reassessed. That about a quarter of the women's colleges have been without full-time mathematics lecturers has always seemed, in Land's words, "to have been scandalous".

\title{
ASSOCIATION BETWEEN AUROR AE AND VERY LOW-FREQUENCY HISS OBSERVED AT BYRD STATION, ANTARCTICA
}

\author{
By L. H. MART.N, Dr. R. A. HELLIWELL \\ Radioscience Laboratory, Stanford University, Stanford, California \\ AND \\ K. R. MARKS \\ U.S. Antarctic Research Program, Washington 25, D.C.
}

\begin{abstract}
$\mathrm{O}^{\mathrm{B}}$ BSERVATIONS during 1959 at Byrd Station, Antarctica (lat. $70 \cdot 5^{\circ} \mathrm{S}$. geomagnetic), show a close association to exist between aurore and certain very low-frequency hiss. The hiss usually occurs in a broad band with a centre-frequency of about $8 \mathrm{kc} . / \mathrm{s}$. The intensity and band-width vary with ionospheric absorption and may also vary with the intensity of the aurore. Under conditions of extreme ionospheric absorption, the intensity of the hiss drops to undetectable levels even in the presence of intense and active aurore. There are some indications that the centre-froquency of this auroral hiss may be related to the type of aurora ; in particular, a centre-
\end{abstract}

frequency of $9.6 \mathrm{kc} / \mathrm{s}$. appears to be associated with red aurora. The average field intensity of the auroral hiss lies between $1 \mathrm{mV} . / \mathrm{m}$. and $3 \mathrm{mV} . / \mathrm{m}$.

The hiss was roceived with equipment designed for the study of whistlers and related very low-frequency phenomena. This equipment consists essentially of a large vertical-loop antenna matched to a wideband $(150 \mathrm{c} . / \mathrm{s} .-30 \mathrm{kc} . / \mathrm{s}$.) audio amplifier. The signals received were automatically recorded for $2 \mathrm{~min}$. each hour. Auroral data were obtained visually as part of the regular International Geophysical Year programme. 